\title{
A CLASS OF NONLINEAR THIRD-ORDER BOUNDARY VALUE PROBLEM WITH INTEGRAL CONDITION AT RESONANCE
}

\author{
HABIB DJOURDEM
}

Abstract. We are interested in the existence result for a class of nonlinear third-order three-point boundary value problem with integral condition at resonance. By constructing suitable operators, we establish an existence theorem upon the coincidence degree theory of Mawhin. The result are illustrated with an example.

Mathematics subject classification (2010): 34B15, 34B18.

Keywords and phrases: Boundary value problem at resonance, coincidence degree theory, Fredholm operator, integral condition.

\section{REFERENCES}

[1] A. Boucherif, S. M. Bouguima, N. Al-Malki And Z. BenbouZiane, Third order differential equations with integral boundary conditions, Nonlinear Anal., 71, (2009), 1736-1743.

[2] N. BOUTERAA AND S. BENAICHA, Existence of solution for third-order three-point boundary value problem, Mathematica, 60 (83), 1 (2018), 21-31.

[3] N. BouteraA AND S. BENAICHA, Nonlinear boundary value problems for higher-order ordinary differential equation at resonance, Romanian Journal of Mathematics and Computer Science., 8, 2 (2018), 83-91.

[4] H. DJourdem AND S. BenAicha, Existence of positive solutions for a nonlinear three-point boundary value problem with integral boundary conditions, Acta Math. Univ. Comenianae., 87, 2 (2018), $167-177$.

[5] H. Djourdem And S. Benaicha, Solvability for a nonlinear third-order three-point boundary value problem, Universal Journal of Mathematics and Applications., 2, 1 (2018), 125-131.

[6] Z. Du, G. CAI AND W. GE, A Class of third order multipoint boundary value problem, Taiwanese Journal of Mathematics., 9, 1 (2005), 81-94.

[7] Z. DU, B. ZHAO AND Z. BAI, Solvability of a third-Order multipoint boundary Value problem at resonance, Abstract and Applied Analysis., Volume 2014, Article ID 931217, 8 pages.

[8] J. M. GALLARDO, Second-order differential operators with integral boundary conditions and generation of analytic semigroups, Rocky Mountain Journal of Mathematics., 30, 4 (2000), 1265-1291.

[9] A. GueZane-Lakoud And A. Frioui, Third Order Boundary Value Problem with Integral Condition at Resonance, Math. Comput. Sci., 3, 1 (2013), 56-664.

[10] A. Guezane Lakoud, R. Khaldi And A. KiliçMan, Solvability of a boundary value problem at resonance, Springerplus., 5, 1 (2016), ID 1504, doi:10.1186/s40064-016-3172-7.

[11] Y. GuO AND F. YAng, Positive Solutions for Third-Order Boundary-Value Problems with the Integral Boundary Conditions and Dependence on the First-Order Derivatives, Bound. Val. Prob., (2013), 6 pages, doi:org/10.1155/2013/721909.

[12] G. L. Karakostas And P. Ch. Tsamatos, Multiple positive solutions of some Fredholm integral equations arisen from nonlocal boundary-value problems, Electronic Journal of Differential., 30, (2005), 1-17.

[13] Y. Lin, Z. DU AND F. MENG, A note on third-order multi-point boundary value problem at resonance, Math. Nachr., 284, 13 (2011), 1690-1700.

[14] A. Lomtatidze And L. Malaguti, On a nonlocal boundary value problem for second order nonlinear singular differential equations, Georgian Mathematical Journal., 7, 1 (2000), 133-154. 
[15] J. Mawhin, Tobological degree Methods in Nonlinear Boundary Value Problems, NSF-CBMS Regional Conference Series in Mathematics, Amer. Math. Soc 40, Providence, RI, 1979.

[16] R. Khaldi AND M. Kouidri, Solvability of multipoint boundary value problems with integral boundary condition at Resonance, International Journal of Analysis and Applications., 16, 3 (2018), 306-316.

[17] J. P. SUN AND H.-B. LI, Monotone positive solution of nonlinear third-order BVP with integral boundary conditions, Boundary Value Problems., 2010, (2010), Article ID 874959, 12 pages. 